Acta Biologica Plantarum Agriensis 5(1): 62 (2017) ISSN 2061-6716 (Print), 2063-6725 (Online) http://abpa.ektf.hu/
DOI:10.21406/abpa.2017.5.1.62

$4^{\text {th }}$ CC 2017 Abstract

Poster

\title{
LIFE ON SAND DUNES FROM LICHENS POINT OF VIEW - EFFECT OF MICROCLIMATE AND SEASONALITY ON ACTIVITY OF TERRICOLOUS LICHEN COMMUNITIES
}

Élet a homokbuckákon a zuzmók szemszögéből - mikroklíma és szezonalitás hatása talajlakó zuzmóközösségek aktivitására

Katalin VERES ${ }^{1}$ \& Zsolt CSINTALAN ${ }^{2}$

${ }^{1}$ Institute of Ecology and Botany, MTA Centre for Ecological Research, Hungarian Academy of Sciences, H-2163 Vácrátót, Alkotmány u. 2-4., Hungary; ${ }^{2}$ Institute of Botany and Ecophysiology, Szent István University, H-2100 Gödöllő, Páter K. u. 1, Hungary; e-mail: veres.katalin@okologia.mta.hu

Terricolous lichen communities are widely distributed in the Kiskunság Region, however we have limited information about the photosynthetic activity of the species living in different microhabitats. In consequence of the dominant wind direction, sand dunes of this region have mainly North-East (NE) and South-West (SW) exposure. These more humid (NE) and more arid (SW) slopes ensure diverse microhabitats for terricolous lichen species with different environmental requirements. To ascertain the effect of microclimate and seasonal weather conditions beside chlorophyll fluorescence measurements and photosynthetic pigment composition analysis, two HOBO micrometeorological stations (with $\mathrm{T}_{\text {soil, }}$ $\mathrm{WC}_{\text {soil, }} \mathrm{T}_{\text {air, }} \mathrm{RH} \%$ and PAR sensors) were placed on NE and SW facing slopes of a sand dune near Bugacpuszta. During the three year continuous data collection we got an inside view of lichen's everyday living conditions. The most considerable differences between the two microhabitat types were in $\mathrm{T}_{\text {soil, }}$ in irradiation and in relative humidity. In greater detail, degree and trend of variation in parameters changed during the day, and showed characteristic seasonality. We observed significant differences in all micrometeorological parameters between seasons during the years. In long-term on SW facing slope because of averagely higher air temperature $\left(0,2^{\circ} \mathrm{C}\right)$ and lower air humidity $(0,5 \%)$ the vapour pressure deficit is higher $(0,2 \mathrm{kPa})$ than that of on NE facing slopes. The higher incoming irradiation on SW side causes higher soil temperature, and lower soil water content. PAR, $\mathrm{WC}_{\text {soil }}$ and $\mathrm{T}_{\text {soil }}$ showed significant difference between microhabitats in every season. In summer probably the short active periods on both types of microhabitats cause smaller difference in $\mathrm{Fv} / \mathrm{Fm}$, meanwhile in spring the small difference between more arid and more humid microhabitats can explain with the most beneficial environmental conditions during the year. 